\title{
Mapping the Missionary World: 19th Century Missionary Atlases with Special Regard to Justus Perthes' Production
}

\author{
Mirela Altic \\ Institute of Social Sciences, Zagreb, Croatia, mirela.altic@gmail.com
}

Keywords: $19^{\text {th }}$ century, missionary cartography, thematic mapping, atlases, Justus Perthes, Gotha (Germany)

\begin{abstract}
:
Often called "The Great Century of Missions" (Kenneth Latourette, 1970), the nineteenth century marked a turning point in the way that missionary issues were mapped. The expansion of missionary societies brought the issue of systematization and visual presentation of extensive data related to missionization to the fore. At the same time, the development of state and church statistics in the nineteenth century facilitated the production of thematic ecclesiastical cartography. The same was also true for missionary atlases which, in this period, experienced a strong development.

The paper analyses the production, reception and distribution of mission atlases during the nineteenth century, with a special focus on the Allgemeiner Missions-Atlas (Gotha, 1867-1871) and other Justus Perthes' missionary atlases, as well as on their impact on the production of similar thematic atlases throughout the world. In the analysis of the missionary atlases, the essential issues which need to be answered are: which missionary facts were mapped; which methods of collecting data were applied; how mission data were linked to other geographic data (climate, communications, languages, race, dominant local region, etc.); which statistical techniques were used; which graphical methods of visualization were applied on the maps; the interrelation between political and ecclesiastical territorial division used on statistical units; which symbolization was applied; which iconographic features these maps had; and how missionary societies spread the modern concept of technology of mapping and the use of professionals in mapmaking and marketing of maps of missions in general.
\end{abstract}

